\title{
National Security in America: Over-Abundance of Caution \& Lack of Practicality
}

\author{
James Pattison ${ }^{1}$, Hakkyong Kim ${ }^{2 *}$, Sungyong Lee $^{3}$ \\ ${ }^{1}$ Dept. of Police Administration, Keimyung University \\ 1095 Dalgubeol-daero, Dalseo-gu, Daegu, Korea \\ James.Pattison@kmu.ac.kr \\ ${ }^{2}$ Dept. of Convergence Security, Sungshin Women's University \\ 2, Bomun-Ro 34Da-Gil, Seongbuk-Gu, Seoul, Korea \\ *pocol@sungshin.ac.kr \\ ${ }^{3}$ Dept. of Police Administration, Keimyung University \\ 1095 Dalgubeol-daero, Dalseo-gu, Daegu, Korea \\ Pol3845@kmu.ac.kr
}

\begin{abstract}
After 9/11, the American intelligence community (IC) grew from few to uncountable, and the money allocated to the community could only be guessed at, given the secret and other funds that accompanied allocated funds for expanding intelligence capability. Out of this spiraling confusion, the Department of Homeland Security (DHS) was born to coordinate the disparate efforts of known and lesser-known intelligence organizations. However, the DHS could not handle the tremendous IC activity by himself, and by 2010, the Office of the Director of National Intelligence (ODNI), the Top Intelligence Officer in America was additionally established. Most of the work in bringing the IC together has been done by the DHS. It seems to have been successful in identifying the directions from which a threat may enter into the country. Where the effort is lacking is when terror comes from so-called "home-grown" or unaffiliated terrorists. For these, a neighborly approach is best, and can be accomplished with minimal investment. The DHS has implemented a reporting system, together with reporting training, which will allow local law enforcement personnel to participate in the national security effort by logging their observations and disseminating them throughout the DHS system. That system is designed not just to collect information, but to share it with participating agencies (including local law enforcement). Part of this initiative is the "See Something, Say Something" campaign that involves private citizens in the national security effort. Of all of the ODNI and DHS efforts, the private citizen observation campaign holds the most realistic promise and provides the best lesson for nations that would learn from the American terrorism response experience.
\end{abstract}

Keywords: IC, 9/11, ODNI, DHS, “See Something, Say Something” campaign

\section{Introduction}

America's anti-terror program consists of a two-fold approach: domestic threat watch and foreign prosecution of a campaign to find and eliminate command structures of organizations posing the greatest terror threat to the United States. Prosecution of the foreign campaign is beyond the scope of this paper, although it is a fluid topic demanding constant scrutiny, report, and revision.

${ }^{*}$ Hakkyong Kim is a corresponding author. 
Domestic infrastructure, such as preserves national security against terrorist threat is only slightly more static a topic to discuss as post " $9 / 11$ " efforts to find the "enemy within us" have created what the Washington Post called a "top-secret world ... so large, so unwieldy and so secretive that no one knows how much money it costs, how many people it employs, how many programs exist within it or exactly how many agencies do the same work" [1]. Studying the network of agencies and companies that live in the Secret world is so entirely overwhelming, given the massive volume of information that such could never be responsibly discussed in the short space of a 10 or 20 - page article without the use of generalizations so broad that the lack of specificity would render the article meaningless. Narrowing the focus to Top Secret organizations and efforts filters the volume enough that we can begin making sense of the apparatus, but only slightly. Nevertheless, it is the American Top Secret anti-terror security apparatus that we shall discuss.

In the intelligence collection business there are many ways to collect information: Photint (photographic intelligence), elint (electronic intelligence), humint (human intelligence), and a host of other "ints" collect data and information from a variety of sources. "All-source" intelligence is that which gleans intel from whatever source derived, so long as it contributes to the overall picture/project undertaken. Specialization in the intelligence field allows experts to flourish in their element and produce the highest quality intelligence for their specialty. However, this same specialization and compartmentalization disallows the free flow of information from one agency or company to another.

\section{History of Department of Homeland Security and the Office of the Director of National Intelligence}

America's Department of Homeland Security was started in 2002 in direct reaction to the 9/11 (2001) Twin Towers terrorist attack in New York City and Washington D.C. One of the terrorist airliners was forced to crash in Pennsylvania during the crisis. Eleven days after 9/11, Pennsylvania governor Tom Ridge was appointed to the newly and hastily formed Office of Homeland Security in the White House. The office was tasked with oversight of and coordination of a comprehensive national strategy to safeguard the country against terrorism and respond to any future attacks [2]. Passage of the Homeland Security Act by Congress in November 2002 made the DHS an official stand-alone Cabinet-level department to further coordinate and unify national homeland security efforts. The Department opened its doors for business in March, 2003.

As we might note from the 2010 Washington Post article, however, agencies and TS (Top Secret) clearances continued to proliferate in America due, in large part, to the vast amount of money that was thrown at the Intelligence Community in the hope that Intelligence would be able to interdict future terrorist activity in America and something like 9/11 would never happen again [1].

Rather than streamlining America's national security apparatus, the DHS simply added another layer to the system in spite of its efforts to the contrary. So the U.S. Congress commissioned the "National Commission on Terrorist Attacks upon the United States (also known as the "9/11 Commission") to review America's Intelligence Community. The Commission finished its work, and recommended the Creation of the position of National Intelligence Director to coordinate all of the disparate intelligence agencies and companies within America and connect the disconnected. Congress made the creation official with the passage of the Intelligence Reform and Terrorism Prevention Act of 2004 (IRTPA) [3].

President Bush signed the bill into law, and the Office of the Director of National Intelligence (DNI of the ODNI) was finally established in April, 2005. The ODNI extends its authority over the actions of the following Intelligence Organizations in America: Air 
Force Intelligence, Army Intelligence, Central Intelligence Agency, Coast Guard Intelligence, Defense Intelligence Agency, Department of Energy, Department of Homeland Security, Department of State, Department of the Treasury, Drug Enforcement Administration, Marine Corps Intelligence, National Geospatial-Intelligence Agency, National Reconnaissance Office, National Security Agency, and Navy Intelligence. Essentially, this places the DNI in organizational control of the DHS. The rest of the DNI subordinate organizations are a mixture of domestic and foreign intelligence-seeking organizations [3].

\section{Missions of the DHS and ODNI}

The ODNI set about, immediately upon its formation, gaining control of the disparate collection, reporting, and mission focuses of the members of the American intelligence community. Using a 100 - day play for integration and collaboration, and then a 500 - day plan, the ODNI keeps constant vigilance to recognize the import of the separate organizations, but to foment an environment of cooperation and common purpose among them. The ODNI regularly publishes a National Intelligence Strategy which updates the intelligence community's concerted goals and achievements. The most National Intelligence Strategy was unveiled in 2014 [4].

The DHS is the workhorse of domestic IC coordination regarding terrorist threat warning and analysis. Today, the DHS pursues five homeland security missions: 1) prevent terrorism and enhance security, 2) secure and manage borders, 3) enforce and administer immigration laws, 4) safeguard and secure cyberspace, and finally 5) ensure resilience to disasters [5]. DHS reviews its progress toward accomplishing its missions periodically with a Quadrennial Homeland Security Review (QHSR), the last of which was conducted in 2014. In addition to the Reviews, the DHS follows a Strategic Plan, the latest of which is the FY 2014-2018 Strategic Plan. This plan details the missions more fully, and states plainly the progress in meeting goals by certain components since the previous Plan was published (in the Appendix B) [6]. The QHSR 2014 goes on to list the roles and responsibilities of each of the national security DHS participants [7].

Most of the ODNI and DHS documents state in painfully managerial terms the lofty goals of the American IC, but DHS has actually implemented some initiatives that make the rhetoric tangible. For instance the DHS provides a vast set of opportunities for everything from citizen involvement in immigration or reporting activities to law enforcement, cybersecurity, electronic crime, emergency management, and other training [8]. However, of all the ODNI and DHS programs and agencies, the most practical in immediate circumstances is the DHS's "See something, say something" program.

With the U.S. Department of Justice's Nationwide Suspicious Activity Reporting Initiative (NSI) to train state and local law enforcement to recognize behaviors and indicators of terrorism and terrorism-related crime, the system standardizes how these observations are documented and analyzed and ensures that reports are shared with the Federal Bureau of Investigation-led Joint Terrorism Task Forces for investigation and with state Fusion Centers for analysis. The "If You See Something, Say Something ${ }^{\text {TM" }}$ campaign raises public awareness of the indicators of terrorism and terrorism-related crime, as well as the importance of reporting suspicious activity to state and local law enforcement. Only those reports documenting behavior that is reasonably indicative of terrorist activity will be shared with federal and SLTT partners [9].

\section{Dangers of Muscle-Bound American IC}

Against the vast backdrop of an ever-expanding American Top Secret Intelligence Community that is virtually paralyzed with specialized expertise, it was an individual that tackled the Christmas Day underwear bomber and saved the day aboard Northwest 
Airlines flight 253 bound for Detroit. In the end, the nature of Terrorism demands a vigilant citizen response with the assistance of government disseminated information [1].

The essence of terrorism is asymmetrical conflict. Terrorist organizations have neither the organization, territory, nor human or other resources of a recognized nation-state. So their aggression against nation-states bears little resemblance to the assaults that a belligerent nation-state may be expected to bring against another. Attacks from such groups exploit creativity, target vulnerabilities, and will morph into new approaches to terror more quickly than heavy infrastructures can react to or address them. Much more stark is the contrast between unaffiliated (albeit possibly sympathetic to organizations) terror-actors like "home-grown terrorists" that develop a propensity toward violent extremism from within the targeted population and that undertake extreme actions to bring attention - often any kind of attention - to a cause.

Whether independent actors or members of a terror organizations, violent terrorists must overcome their natural inhibitions against killing innocents. The process of bringing concerned members or citizens to the point of their willingness to commit atrocities that the victim population will most react to is often called, "radicalization." Radicalization has taken on a definition of the joinder of extremist beliefs with the willingness to undertake extreme behavior implied by those heart-felt extreme beliefs. The term has largely been co-opted by media looking for overly simplistic explanations for apparently inexplicable events. But while simple answers are immensely gratifying to a scared and ignorant population, they are merely salves at best, and are dangerously distracting at worst. Gaining understanding makes people feel better about confronting the unknown. But when the population focuses its attention upon a straw-man threat, the real threat creeps up behind and attacks again.

What do terrorists look like? How can psychological profiles, personality trait complexes, life experiences among those "at risk" help us to identify terrorists before they pose a threat to society? What is the role of ideology in terrorism? How is a potential terrorist "radicalized" to the point that he/she will undertake violent aggression against innocents? These are questions that might best serve to prepare a nation to ferret out the immediate terror threats to its people and possibly its very existence. Horgan and Taylor (2001) noted that "...there is rarely a conscious decision made to become a terrorist. ... (It) results from gradual exposure and socialization towards extreme behavior [11]."

In the area of terrorist-related scholarship (an area as yet not fully developed) Martha Crenshaw is a most prominent figure. Over the past 30 years Ms. Crenshaw has expanded upon her 1985 suggestion that terrorists are motivated to act or join an active terror organization by any one or a combination of 4 things: (1) the opportunity for action, (2) the need to belong, (3) the desire for social status, and (4) the acquisition of material reward [10]. Borum, another scholar, has reduced the list of motivations or vulnerabilities to greater openness to extreme behavior as something to do with the terrorist's perceptions of (1) injustice, (2) personal identity, and (3) need for belonging [12]. Combining Crenshaw's list with Borum's we might associate the notion of perceived injustice with the opportunity for action, one potentially begetting the other where injustice may be perceived in economic, ethnic, racial, legal, political, religious, and/or social spheres of societal relations. Crenshaw's second motivation, "the need to belong," and Borum's third, "belonging" both suggest that the meaning, purpose, and sense of connectedness appeal to would-be terrorists seeking to be a part of a community of believers (in whatever ideology...the exact ideology being secondary to the terrorist to affiliation with the community itself...). And the social status of Crenshaw's list easily integrates with Borum's notion of identity where identity is a collection of a person's values, attitudes, and beliefs.

Taylor and Louis (2004) put it regarding recruitment into a terror organization,

"These young people find themselves at a time in their life when they are looking to the future with the hope of 
engaging in meaningful behavior that will be satisfying and get them ahead. Their objective circumstances including opportunities for advancement are virtually nonexistent; they find some direction for their religious collective identity but the desperately disadvantaged state of their community leaves them feeling marginalized and lost without a clearly defined collective identity [13, at 178]."

In essence, terrorists look like everybody that grows up with the challenges of forming a personal identity, finding life purpose and meaning. And that is just about everybody. There is nothing in psychological formation of an individual that is specifically identified with a would-be terrorist. Certainly, there is nothing that an intelligence community can exploit to identify future threats to security and exploit for further prophylactic purposes.

Emerging terroristic thoughts have to do with a righteous indignation that a person feels, starting with the realization that "It's not right," related to "some perceived restriction or deprivation in a person's environment [14]." This is followed by an impression that the aversive condition is "not fair," because an "oppressed group's" reasonable expectations are not realized or realizable - a perception of "unjustness" fomenting feelings of resentment [14]. Recognizing discrepancy between entitlement and an unsatisfied status quo yields naturally to an assignment of blame, which Borum calls "It's your fault" thinking, or the targeting of resentment toward specific others [14]. And to carry this thinking process to a violent conclusion, according to Borum, some individuals will either cast the perceived oppressors as aggressive toward them, demanding their action in self-defense, or they may demonize them, "casting them as "evil"' so as to justify their taking extreme measures to confront the oppressor [14].

"Research on the psychology of terrorism has been nearly unanimous in its conclusion that mental illness and abnormality are typically not critical factors in terrorist behavior. ... Moreover, although terrorists often commit heinous acts, they would rarely be considered classic 'psychopaths' [12]."

Early terrorism scholarship suggested that a terrorist "profile" can be developed such that would-be terrorists would be recognizable to some vague degree. Russell and Miller offered such a profile which included such characteristics as

"Age: Generally 22-25 for members. Sex: $80 \%$ of operations led and directed by males. Marital Status: Most unmarried. Urban/Rural: Most urban terrorists are natives or long-time residents of metropolitan areas. Socioeconomic: Predominantly middle and upper class for members and leaders. Education: Two thirds had at least some university training. Recruitment site: Large universities are the primary sites. Political philosophy: The three tendencies at play in terrorist organizations at the time were anarchism, Marxism-Leninism, and nationalism [12]."

While profiling is attractive, even intoxicating, to governments that seek to identify terrorists and interdict their activity before even the "terrorists" know that they are, or will be, violent extremists, the reality is that profiles such as Russell and Miller's identify such a broad portion of the population of almost universally non-terrorists, that it is essentially useless as a prism, and potentially devastating a misdirection. As Silke put it, "the belief that profiling can provide an effective defense also seriously underestimates the intelligence of terrorist organizations [15]."

"Most observers agree that although latent personality traits can certainly contribute to the decision to turn to violence, there is no single set of psychic attributes that explains terrorist behavior [16]." Would-be terrorists are not distinguished by a particular set of 
gifts, tendencies, traits, nor anything else that would make them stand out as "different" among the population in general.

Among terrorists there are no common life experiences that set them apart from the general population. On the other hand, there seems to be a common presence of histories of childhood abuse and trauma, and themes of perceived injustice and humiliation among many terrorist biographies [12]. While these may not explain terrorism, these may have some relation to individuals' vulnerability, motivation, or "radicalization" toward terror as a viable alternative tool for addressing injustice.

But again, the problem confronting an enormous intelligence community is how to sift through the details of millions of "underprivileged" or traumatized individuals so as to identify those most susceptible to growing into a terrorist. The task is beyond any intelligence organization however vast or small. Although society may be able to channel the thinking of such people with opportunities and programs that orient individuals' aggressions toward positive uses and outcomes.

\section{For Further Research}

Matters not discussed in this paper that are of equal or greater importance in national understanding and redress of terrorism, homegrown or organizational, are 1) the social nuances that create a climate where terror activities become appealing to the disaffected or disenfranchised in society; 2) the phenomenon of diffusion or displacement of moral responsibility for abhorrent acts that allow otherwise ethical and relatively law-abiding persons to undertake unspeakably violent behavior; 3 ) how terrorists must maintain at least the illusion of a formidable enemy immediately at the gates (that being the target population) in order to maintain cohesion within the terror organization or the intense need for immediate defensive action among individual/homegrown actors; and 4) whether the obviating of the effects of terrorism upon society would render the entire institution of terrorism null, ineffective, and therefore without purpose.

Regarding the first suggestion, it is notable that the so-called "Danish Model" for "deradicalizing" Danes that return from Syria after their having fought with terror organizations has apparently found some success in rehabilitating violent citizens into productive non-threatening members of society. Critics challenge the claims of success quite persuasively. But the overall suggestion of the Danish Model is worth further inquiry: should society at all levels (government and participating citizenry) spend more time nurturing youth, seeing to their moral and economic development, and actively involving the at-risk in productive initiatives, then perhaps there would be fewer disaffected individuals to be "radicalized" in the first place. Rather than focusing upon the de-radicalization of the already violent, though, such research might attend to the institutions established, or that could be established, to re-direct the anti-social impulses of the young before those impulses even find fertile soil in which to implant. Furthermore, the research should allow that it is not necessarily the disadvantaged in society that turn to terrorism as an avocation, but free-thinking academics and religious zealots as well. In fact some of societies' greatest heroes may have found equal "success" and purpose as terrorists. Research in the area of social reform may be most effective in its appreciation of terrorism as a viable alternative to dispute resolution, then, but an alternative that is least likely to yield satisfactory results for the terrorist or terror group.

Some psychological research has been done that illustrates how good, innocent, productive citizens (and students), when part of an organization, and when given direction by a perceived competent authority, will do things to other good, innocent, productive citizens (and students) that would otherwise offend their own (and certainly our) moral senses. The famous Stanford Prison Experiment, among others, shows that it is not unreasonable to expect atrocities from good people that are acting at the command of others that stand ready to assume responsibility for those atrocities. As it applies to 
terrorism, the concept suggests that taking the moral responsibility for heinous acts away from an actor empowers the actor to act in extraordinarily hideous ways. Research in this area might exploit the phenomenon of displaced moral responsibility and suggest answers to it such as a social emphasis upon personal responsibility even for actions taken in an organizational environment (whether that organization be a religious cult, a terror organization, or a legitimate corporation or government body).

Terrorist organizations, and to a certain extent perhaps individual and homegrown terrorists, seem to arrive at a point where they are psychologically ready to undertake extreme violent action to make an impression upon society. But arriving at the point of being willing to act extremely and staying there are two different things. If the first can be called "radicalization," the second (staying there) presents a challenge to the terrorist in the face of internal dissention (or "2nd thoughts") and loss of momentum that some researchers suggest can be met by identifying, demonizing, and aggrandizing the threat posed immediately to the terrorist or organization. By controlling the minds of terrorist actors so that they remain dedicated, unreservedly and unquestioningly, to the ideological justification for extreme action, and presenting the threat from the target as an immediate ominous threat that must be met swiftly and continuously, the terrorist (and organization) can "keep the initiative" with their terrorist activity. Further research may be fruitful in the area of combating such a "citadel" mentality, thus undercutting the initiative of the terrorist for immediate extreme action.

Not least critical is the idea of taking the "terror" out of terrorism. Terrorism succeeds not in the effectuating of mass destruction and killings, but in instilling fear of the unknown in the population (and their governments). The ominous impression of doom is what people feel as a result of terror attacks, and is precisely the effect that is the goal of terrorist activity. Terrorism is not criminality for criminality's sake, but a means to the end of gaining the attention (positive or negative) of a population to the demands or frustrations of the terrorist. If society is resilient enough to respond to terror in managed, competent, and informed ways without giving the terrorists the satisfaction of their desired effect (inculcated mass hysteria), then perhaps terror as a tool for social change would be less viable an option to extremists. A study of Israel and its experience with terrorism, the desensitization of that nation of people, and the psychological armor protecting its citizens from the long-term effects of repeated terror attacks may be a lesson to other nations that can anticipate the inevitable eventuality of terrorist attack within its borders. Some call this "resilience" to terror acts. But the resilience is not just the notion of being able to absorb the immediate physical and psychological impact of terror attacks, but to respond competently with coordinated competent emergency services that are equipped and trained to respond fluidly to an unlimited variety of threats.

\section{Conclusion}

The American post - 9/11 conclusion, intensified by the ISIS experience currently pressing for attention, is that when the nation's security is threatened people are willing to relinquish a certain amount of freedom and a great amount of taxes to shore up the national defenses against an unknown enemy. Layer upon layer of intelligence agencies and companies, working variously in coordination and at odds, suggest that the American intelligence shield has been created to forestall another 9/11 from ever occurring. The ODNI and the DHS have made a broad variety of efforts to control borders, immigration, travel, and more, so far as it can. But when the terrorist threat is an individual that wakes up one morning and decides to commit an atrocious act of terror, there is no amount of preparation by a top-heavy bureaucracy of intelligence officials that can stop it. Only vigilant and participating citizens can possibly save themselves and others.

The intelligence behemoth can help to prosecutor an anti-terror war abroad, and perhaps even track the movements of known individual threats to the United States. But it 
is powerless to identify, anticipate, interdict terror activity that is not centrally controlled by a terror organization. And these days the homegrown terrorist, or terrorist that would seek to endear him/herself to a more established organization is the elusive threat. Since there is no psychological, personality, nor biographical profile that would narrow the list of potential threat individuals, then only friends, family, neighbors, and fellow citizens have the vantage point to observe out-of-the-ordinary behavior in individuals that may signal pending extremist activity.

Indeed, ultimately the best security mechanism against immediate threat is citizen participation in observation and reporting of unusual activity to authorities. Real terrorist attacks are thwarted when friends, neighbors, relatives or bystanders see something amiss and either report or intervene. Otherwise experience demonstrates that no amount of money can allow intelligence or law enforcement personnel to see into the minds of would-be terrorists.

The implications of this is that citizens must be: 1) made aware of their part in the security of the state, 2) should be rewarded for their effective participation (think paparazzi), and finally 3) police in the community must reach out, gain the trust and cooperation of, and nurture relationships with citizens within their areas of responsibility, creating an environment where the free flow of information and grass-roots vigilance hardens the society against terrorist threat.

\section{Acknowledgements}

This paper is a revised and expanded version of a paper entitled "National Security in America: Response of the American Intelligence Community to 9/11" presented at the third workshop on Security, Reliability and Safety 2015, Jeju, Korea, December 14-16.

\section{References}

[1] Washington Post, http://projects.washingtonpost.com/top-secret-america/articles/a-hidden-worldgrowing-beyond-control/

[2] Department of Homeland Security, http://www.dhs.gov/creation-department-homeland-security

[3] Office of the Director of National Intelligence, http://www.dni.gov/index.php/intelligencecommunity/members-of-the-ic

[4] Office of the Director of National Intelligence: National Intelligence Plan of the United States, Office of the National Intelligence, Washington (2014).

[5] Department of Homeland Security, http://www.dhs.gov/our-mission

[6] Department of Homeland Security: Strategic Plan for Fiscal Years, Department of Homeland Security, Washington (2015).

[7] Department of Homeland Security: Quadrennial Homeland Security Review (QHSR), Department of Homeland Security, Washington (2014).

[8] Department of Homeland Security, https://www.fletc.gov/

[9] Department of Homeland Security, http://www.dhs.gov/see-something-say-something/about-campaign

[10] M. Crenshaw, 'An organizational approach to the analysis of political terrorism', Orbis (1985), vol.29, no.3, pp.465-489.

[11] J. Horgan, and M. Taylor, 'The making of a terrorist', Jane's Intelligence Review (2001), vol.13, no.12, pp.16-18.

[12] R. Borum, 'Psychology of terrorism', Tampa: University of South Florida (2004).

[13] D. Taylor, and W. Louis, 'Terrorism and the quest for identity', in 'Understanding terrorism: Psychosocial roots, consequences, and interventions', Edited F.M. Moghaddam and Marsella, Washington, DC: American Psychological Association (2004), pp.169-185.

[14] R. Borum, 'Understanding the terrorist mindset', FBI Law Enforcement Bulletin (2003), Vol.72, No.7, pp.7-10.

[15] A. Silke, 'Profiling terror', Police Review (2003), Vol.111, No.5737, pp.18-20.

[16] G. H. McCormick, 'Terrorist Decision Making', Annual Review of Political Science (2003), Vol.6, pp.473-507.

[17] B. P. James, H. Kim, and S. Lee, 'National Security in America: Response of the American Intelligence Community to 9/11', Advanced Science and Technology (2015), Vol.117, pp.106110. 


\section{Authors}

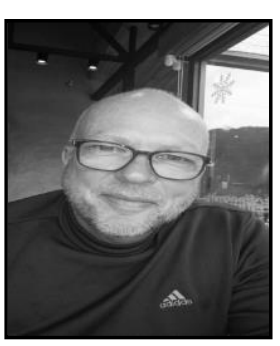

James Bryan Pattison is currently a Professor at the Department of Police Administration, Keimyung University in Daegu, Korea. He received his J.D. from Syracuse University in the United States of America. His research interests include criminology, criminal law, terrorism, and national security.

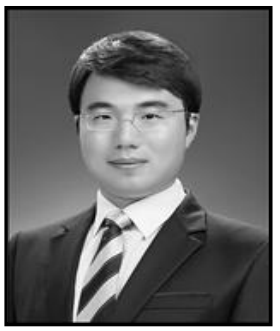

Hakkyong Kim (Corresponding Author) is currently a Professor at the Department of Convergence Security, Sungshin Women's University in Seoul. He graduated from the Korean National Police University in 1999. He earned his MSc degree in Risk, Crisis and Disaster Management from the University of Leicester, UK. He has completed his $\mathrm{PhD}$ research on a comparison of simulation exercises in Korea and at the University of Portsmouth, UK.

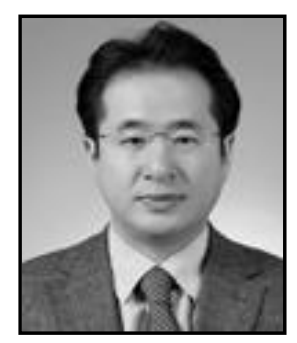

Sungyong Lee is currently a Professor at the Department of Police Administration, Keimyung University in Daegu. He graduated from the Korean National Police University in 1992. He earned his LL.M. and Dr.iur. in Police Law from the University of Augsburg, Germany. 
International Journal of Security and Its Applications

Vol. 10, No. 4 (2016) 